\title{
Key Actors \\ in the Libyan Conflict
}

Friends and Foes of the Libyan Political Milieu

\author{
Andrei V. Chuprygin, Larisa A. Chuprygina, \\ Valery A. Matrosov
}

\section{Abstract}

This article attempts to analyze the current political situation in Libya through the activities of the main actors and a net of opportunistic interactions they create on the national and international levels. The paper scrutinizes Libya's three governments and the tribal factor, and also considers the role of neocons

\author{
Andrei V. Chuprygin, Senior Lecturer \\ National Research University-Higher School of Economics, Moscow, Russia \\ Faculty of World Economy and International Relations, School of Asian Studies \\ ORCID: 0000-0002-2254-7707 \\ ResearcherID: J-8706-2015 \\ SPIN-RSCI: 3520-0398 \\ E-mail: achuprygin@hse.ru \\ Address: 20 Myasnitskaya Str., Moscow 101000, Russia \\ Larisa A. Chuprygina, Senior Lecturer \\ National Research University-Higher School of Economics, Moscow, Russia \\ Faculty of World Economy and International Relations, School of Asian Studies \\ ORCID: 0000-0003-4783-6211 \\ ResearcherID: I-4184-2015 \\ SPIN-RSCI: 8636-0015 \\ E-mail: lchuprygina@hse.ru \\ Address: 20 Myasnitskaya Str., Moscow 101000, Russia \\ Valery A. Matrosov, Lecturer \\ National Research University-Higher School of Economics, Moscow, Russia \\ Faculty of World Economy and International Relations, School of Asian Studies \\ ORCID: 0000-0002-3316-0444 \\ ResearcherID: B-6255-2019 \\ E-mail: vmatrosov@hse.ru \\ Address: 20 Myasnitskaya Str., Moscow 101000, Russia
}


who have recently entered the political milieu and claim their stakes in the future of the country.

An attempt is made to look at international relations theories, specifically the realist conception and the liberal interdependence narrative, and their holistic approach to the state, through the lens of their applicability to the Libyan case, in order to understand the Libyan puzzle and forecast its future development. The study also includes an analysis of the diversity of national and international centers of power in Libya, including existing tribes and clans, and their involvement in the crisis. An effort is made to formulate relevant arguments for future debate, which, in our opinion, is inevitable.

Keywords: Libya, armed conflict, tribal structure, armed militias, crisis of state power, statism, realist, liberal

\section{SETTING THE RESEARCH BACKGROUND}

Colonel Gaddafi's regime led to the formation of a one-man state in Libya. Its unification since 1969 depended not so much on the institutional structure, which was in full compliance with the concept of "stateless society" within the framework of the new ideology formulated in the "Green Book" (Smits, 2013, p. 11), but rather on the leader's personal charisma and connections, as well as on the archaic communication models (Lacher, 2011). A similar approach was used towards the country's international relations, where the leader's personality and deep coffers were considered crucial for bilateral and multilateral relations, placing Libya and its leader in the center of an "imaginary universe." So, it was not surprising that after Gaddafi's death Libya got fragmented into multiple factions; nor is it surprising that it lost a proactive position in the international relations system following the loss of a positive IR discourse. Moreover, the breakup of the leader's "imaginary universe" threw the country into the reactive corner of international politics, making it fall victim to the regional and international ambitions of close and far neighbors.

Since the overturn of 2011, which is often viewed as part of the Arab Spring, Libya has lived through eight years of instability, violence, and 
civil war. Different groups and movements, shifting alliances (whose composition more often than not is not related to ideological views), different governments (each seeing itself as the sole legal authority) make the research of this conflict a very complicated task. The number of actors involved in this struggle and competing for resources, minds and power is incredibly large, while their intentions, motives and possible future behavior are unclear. In addition to the local specifics, there are international actors, such as Italy and France (and Russia not far on the horizon), which rushed in to fill the void of the Libyan space in international relations-politically and economically.

The main purpose of the present research is to determine whether there is still a factor powerful enough to ensure the country's unification. To achieve this objective, we must find answers to several crucial questions: What are the centers of power in Libya today? How did they shape up? What do the leaders of these centers seek to achieve? What are the interdependencies between the national and international factors in the Libyan crisis? This enormous task is complicated by the lack of reliable empirical data.

First, we have to determine who exactly can be considered the true leader of Libya. In the case of a conservative tribal state, a leader is not only the one who occupies a position of power and possesses political leverage, but the one who also enjoys enough legitimacy. The position of power in Libya is seen in its traditional hierarchical paradigm, where the pedigree plays the role equal to that of money and military resources in building an influential position. So, in order to determine the true leader, we must evaluate his ability to reunite the country, his supporters, intentions, ways of communication with others, and his strong and weak spots that help him gain power or stand in the way.

Our analysis has shown that both the realist and the liberal interdependence narratives cannot be applied to the case of Libya as they do not distinguish between the state, government, and society (Thomson, 1995). More helpful is Krasner's (1984) statism theory with the "Us versus Them" dichotomy, where the state is seen as "Us", and "Them" is regarded as other states and own society. This formula is more helpful for understanding the Libyan backstage, although the 
answer to the question "What is the state?" remains obscure. The current developments in Libya, which have resulted from eightyear-long political and social turmoil, have triggered a complete and irrevocable demise of the traditional late-twentieth-century state governance construct. At the same time, we argue that given all its complexities, both internal and external, Libya is not ready for a bottom-up restructuring of state governance. As the majority of Libyan young constituencies seek an exit from the "neo-traditionalist" statehood, a "post-Westphalian" arrangement is not welcome by its close and far neighbors, as they inevitably perceive it as a clear and direct threat to their own authority and legitimacy.

The historiographic material dedicated to the Libyan crisis is quite diverse and complex (as well as rather inaccurate, ambiguous and biased). So the present study is based on a variety of sources, from academic research literature, such as the works of Wolfram Lacher, to news releases, from Arabic outlets dedicated to specific problems to general American "guides" and provocative Russian essays on several relevant issues.

Although the relevant sources do not provide answers to our satisfaction (giving a precise forecast or naming exact persons and political groups is hardly possible, anyway), we believe that a close look at the Libyan crisis through the prism of the leadership evolution may help understand the current trends, the balance of power and political hierarchy in modern Libya.

\section{LIBYAN HISTORICAL CONTEXT}

The state of Libya was established rather arbitrarily by Western powers under the 1951 agreement, which brought together three regions: coastal Tripolitania and Cyrenaica, and the desert of Fezzan. The UN declared these territories a united independent state and entrusted the three different regions, each with a different social and tribal system, to King Idris I al-Senussi (1951-1969). In a sense, the country was created in line with an international relations conception and, logically, should be analyzed through the relations between internationally recognized actors. However, Western powers did not pay much attention to the 
regional specifics, which became even more pronounced after oil was found in the eastern region of Cyrenaica (Barca in Arabic) (Smits, 2013, p. 10-11). Throughout the years of the monarchical rule, the main unifying factors were related to religion (due to the legacy of alSenussi Sufi network), while the main dividing factors were economic.

After Muammar al-Gaddafi (1969-2011) had overthrown the monarchy and introduced a new socio-political model, he started a decade-long search for factors that would strengthen the country's unification. His reforms, which made concessions to tribes by granting them privileges and liberties, as well as his demographic policy towards several social groups (especially township youth and ethnic minorities) contributed to Libya's unification, although three of its parts were never completely tied to each other either by traditional and cultural bonds or by a developed infrastructure (Ladjal, 2016, p. 6). Hypothetically, the two most advanced regions (Tripolitania and Cyrenaica) still have a potential to exist separately from each other and from Fezzan, even though Fezzan supplies oil (which is crucial for Libya's economy) and water (which is a scarce commodity and its discovery in the middle of the Libyan desert increased demographic and economic prosperity on the coast) (Za'rab, 2016).

At the same time, the controversy between the policy of creating an "imaginary nation," on the one hand, and the tribal diversity exacerbated by conflicts between the Bedouins (one of Gaddafi's political vectors that will be discussed below), on the other, made Libyan society fragile and unstable. This factor laid the groundwork for immediate stratification of the Libyan space when the Gaddafi's rule crumbled.

As unrest began in February 2011 in Benghazi (Cyrenaica), mutinies swept across all eastern cities of Libya, where economic and political grievances had been growing over Gaddafi's long rule, and soon rag-tag militias comprising local civilians appeared in many towns, rural areas and desert regions. Some of the opposition forces in the eastern provinces succeeded in forming a united coordinating body凶the National Transitional Council (NTC), whose brigades immediately got air support from NATO (Smits, 2013, p. 15). 
When the West intervened in the conflict, the Libyan state collapsed, creating a power vacuum. The last significant strongholds of the Gaddafi regime were Tripoli and the leader's native city of Sirte. In August 2011, the opposition and NATO forces captured the capital, and in October Sirte fell and Gaddafi himself was killed by the rebels.

Soon it became clear that the unity of the dissimilar opposition forces was rather fragile (if there was any at all). Several groups from Cyrenaica felt nostalgic about the monarchy (Lacher, 2013, 20), which was expressed in the adoption of the old Libyan Kingdom's flag as the official flag of the state. The liberal-nationalist parties voted for democratic elections and transformation of the country's authoritarian political system into a Westernized progressive one.

After the parliamentary elections, which took place in July 2012, the NTC disbanded itself and was replaced by the General National Congress (GNC). The most popular political force became the National Forces Alliance, closely followed by the Justice and Construction Party (JCP), a political wing of the Libyan Muslim Brotherhood. In a bid to prevent the formation of a clear majority in parliament and promote the interests of all groups and movements, 120 seats out of 200 were divided between independent candidates (Smits, 2013, p. 19).

However, these elections showed the lack of democratic traditions in Libya, as the leading actors gained their votes simply through establishing contacts with tribal leaders (Report Libya, 2014). As a result, the divisions in the country became even more profound. The government soon lost (or rather had not even established) control over the natural resources in the south of Cyrenaica, as well as over the cities of Bani-Walid and Misrata (Lacher, 2013, p. 13). The local tribal councils replaced the GNC councils in many cities and towns, and the government had nothing left to do but recognize them as local governing bodies. In a short while, Misrata became the consolidating center of an impressive military force, while Bani-Walid evolved as a successful city-state.

The crisis was aggravated by the blockade of oil supplies, which provided the biggest share of the Libyan national income: the so-called Petroleum Facilities Guard (PFG) took under its control several oil 
fields and major oil ports, and by shutting down the pipelines stopped oil supplies from the southern parts of the country to the coast.

At the same time, the Islamists from groups like Ansar al-Sharia (associated with al-Qaeda, estimated at about 5,000 fighters in Libya (Report Libya, 2014)) established control over Benghazi, Derna, and Ajdabiya in Cyrenaica, and Sirte in Tripolitania. Ansar al-Sharia became one of the most powerful organizations owing to its charity funds used to attract local population and to support camps for training foreign fighters, as extremists were flooding the country from Tunisia and Egypt (Fitzgerald and Toaldo, 2016).

In 2014, the main events evolved around the confrontation between General Khalifa Haftar and alleged Islamists from Benghazi. In February, Khalifa Haftar, former General of Gaddafi and a self-proclaimed opposition activist from abroad, declared the beginning of Operation Dignity against the Islamists in Benghazi, aimed at building a coalition of different groups, including secular militias, tribal armed groups, and even some Salafis. Haftar called this coalition the "Libyan National Army" (LNA) and claimed it to be the only effective Libyan military force. As a counterforce to the LNA, another coalition was formed with the center in Tripoli and Misrata, called Libya Dawn, which included different actors, varying from explicitly Islamist groups to powerful militias to senior military figures from former Libyan Army.

At the same time, scores of Libyan embattled radicals, who had been engaged in wars in several parts of the world, started to return to the country, and pledged their allegiance to ISIS, like other foreigners and mercenaries. These ISIS militias succeeded in consolidating their positions on the Libyan coast, making Sirte their stronghold.

In May 2014, the GNC was replaced by the House of Representatives (HoR), which mainly represented forces associated with Operation Dignity. However, many of the GNC's members and their supporters, in particular the Islamists, resisted Haftar's secular orientation and his image as "Qaddafi reincarnate," and did not recognize the newly established HoR. They took their revenge and occupied Tripoli, so that the HoR had to hold its first session in Tobruk (Cyrenaica, under Haftar's control), as former GNC members and some representatives 
from radical forces formed the New GNC (referred to as the GNC below) in August 2014.

By the end of the summer of 2014, Libya had actually turned into a collection of city-states (Fitzgerald and Toaldo, 2016), which clashed with each other and juxtaposed or intersected with multiple tribes, all challenging the state's sovereign right to authority, including crossborder representation, thus defying the arguments of both realists and, to a certain extent, liberal international relations theorists. The struggle continued until November 2015, when a new Special Representative of the UN in Libya, Martin Kobler, insisted on the continuation of the political dialogue between several opposing factions in Morocco, which resulted in the Skhirat Agreement in December. According to this document, a Government of National Accord (GNA) and a Presidential Council (PC) were formed, and Fayez al-Sarraj, former minister in the GNC, became prime minister (and the head of state).

\section{LIBYA IN 2016: THE GOVERNMENT AGAINST PARLIAMENT}

Although the political dialogue resulted in the formation of a new government, it did not solve Libyan problems, and the next few months were overfilled with contradictions and struggle. The failure to reach a compromise between major actors was evident. In March 2016, the GNA arrived in Tripoli from abroad; and as the interests and proposals of the House of Representatives had been considered in the negotiations only to a small degree, by the end of the summer of 2016 the HoR once again had declared itself the only legal authority in the country and refused to comply with the provisions of the agreement.

To legitimize his position, Fayez al-Sarraj decided to start his term of office by clearing Sirte of ISIS forces. Actually, Tripoli did not have enough military power and had to negotiate with other forces, among which the LNA, Misrata brigades and the PFG groups were the most powerful. Khalifa Haftar, who often claimed to have conquered Sirte, refused to cooperate with al-Sarraj and preferred to wait until the campaign ended. The Misrata authorities decided that this war might be used as an opportunity to broaden their sphere of influence, and resolutely supported the GNA. So did the PFG, in order to consolidate 
their control over oil ports and infrastructure facilities situated not far from Sirte.

The city was cleared of Islamists by December 7. The battle of Sirte was not only a test for the GNA's military capability, but also for its political solidity. As many brigades took part in the Sirte campaign, some supporters of the GNC unleashed street fighting in Tripoli in an attempt to bring back their old government, but the GNA successfully curbed the attempt.

The victory over Sirte should not be considered as an unambiguous positive step because al-Sarraj and Misrata elders directed all their forces to this goal and completely ignored pressing social problems (cash and electricity). Yet this victory impressed foreign actors, who began to consider al-Sarraj and the GNA more seriously. Moreover, it was possibly one of the factors that hindered the Eastern Libya separation movement: against the background of the hesitant leaders of Cyrenaica and the divide between political elites and tribal leaders, the success of Tripoli could not go unnoticed.

Historically, Barca is the core and the heart of the Libyan statehood and used to be the most centralized region during the period of colonial occupation. The network of Sufi Senussi brotherhoods in towns and tribes contributed to close ties between different local forces, and as the aims of tribal sheikhs and Senussi leaders converged, their alliance against Italy and later Britain created a basis for a strong nationalist movement.

Initially, the Senussi Sufis claimed only to rule Barca (Ladjal, 2016, p. 9), and in 1949 their leader, Sheikh Muhammad Idris, supported by the tribal council, published the Barca constitution (Dustur, 1949). During the reign of Muhammad Idris, who became king of united Libya, the eastern tribes enjoyed a lot of privileges; and even though the capital was moved to Tripoli (with Benghazi still maintaining the status of royal city), Cyrenaica held the position of the most developed economic region, which was further strengthened by the discovery of oil reserves on its southern edges in 1959. As-Senussis did not belong to any tribe (they originated from Algeria) and that helped their legitimacy as a national power broker (Borisov, 2007). 
However, during Gaddafi's rule the tribes from Tripolitania became most influential as the positions of Barca's leaders significantly declined (Smits, 2013, p. 27). They did not have direct access to the oil revenues and could not control main infrastructure facilities (airports, seaports and, most importantly, oil ports).

After 2011, the eastern tribes established control over some natural resources (oil, gold, water, and uranium). In order to restore their superiority, they formed the Council of Sheikhs (elders) in Tobruk and cooperated with the HoR against Tripoli, because the tribal leaders feared that the GNA may try to regain exclusive control over their resource base, thereby preventing the sheikhs from the distribution of the revenues (Lacher, 2011).

By the beginning of July 2016, several documents had been drafted to the effect that the sheikhs of the Cyrenaica tribes made a declaration by which their support of the Barca state was declared publicly (Shibh at-taqsim, 2016). In the next six months the elders were to appoint Head of the Council to play the role of president and prepare a draft constitution to be further accepted by the people of Barca in a referendum. They were also expected to form basic political structures and executive bodies and appoint their top officers. However, none of these tasks was implemented.

To understand the reasons for this failure, one has to examine the tribal structure of Libya, where a tribe is an institution within the framework of modern Libyan society.

\section{LIBYAN TRIBES}

Libyan tribes are the main factor of the state's development, and thirty of them have a strong impact on domestic and foreign policies (Ladjal, 2016, p. 2). Most Libyan cities are small groups of buildings surrounded by thousands of tents, as the tribes still maintain their nomadic lifestyle.

Each Libyan tribe has its own sphere of control, named watan, and its reach depends on the size of a settlement. The southern tribes (in the south of Cyrenaica and in Fezzan) have less developed relations with villages and the town, but they have control over 
larger areas even if smaller in absolute numbers of the population compared to the northern tribes. In this context, two main factors should be considered.

First, the south of Libya is the most valuable region from the economic point of view, as it has large oil and water reserves. If the tribes fail to reach agreement with the political centers on the coast, these reserves become inaccessible for coastal cities, which can cause a nationwide economic crisis.

Second, the south is an uncontrolled region, which was often used by extremist groups to channel weapons and manpower by the roads extending over the Sahara Desert. If not controlled, the borders between Libya and neighboring states like Chad, Niger, Algeria, and Sudan become an open gate for the Islamists (Sayigh, 2016, p. 12).

The first factor means that the lack of agreement with the tribes threatens not only international trade (as oil is the main export commodity), but the very existence of coastal areas. The second factor means that the extremist groups also have some forms of agreement with the nomads, using their watans as supply routes.

To understand the social model by which Muammar al-Gaddafi succeeded in ruling such complicated society, we must look at his concept of a "clan state," whose roots lie in the monarchist model. Similar to King Idris I, Gaddafi solved the problems of tribalism or 'asabiyya (an Arabic synonym for tribalism, but also meaning tribal pride and clan devotion (Ladjal, 2016, pp. 3-4)) by using the network of Sufi Senussi brotherhoods and centers (or zawiyas, with one zawiya for each town or clan (Sayigh, 2016, p. 8)). The religious factor was placed above the ethnic one, and this approach ensured not only some unity of the tribes, but also a sense of equality. It also allowed the king to control the roads, the borders and the desert regions rich in resources and vital for the development of the state.

Of course, this approach could not solve all local conflicts arising at the intersection points of different watans. The disputes usually emerged over trade routes (and, since the 1960s, also pipelines), and as each tribe tried to strengthen its own control over the routes, they remained safe for traders and travelers, while occasional conflicts, 
overlaid by the religious umbrella of unification, rarely influenced the overall economic situation in the country.

In the Ghaddafi era, this system was reproduced once again. He adhered to the Islamic laws (did not drink wine or alcohol), tribal customs (which is evident in his clothing style) and culture, thereby displaying the requisite signs of piety, clannishness and strength. Although his rule was basically authoritarian, he elaborated an absolutely new model of a clan state, in which every tribe had a chance to participate in state governance (Borisov, 2007).

But the main pillar of the Gaddafi regime was personal alliances with the sheikhs. His power represented not an authoritarian regime in the Western meaning of this word, but the ancient model of charismatic leadership, in which of crucial importance were personal connections, devotion and the skill of negotiating deals with different forces, not through papers and documents but through material resources.

Gaddafi came from the Gaddadfa tribe, so it is not surprising that the members of his tribe held important state positions, although "Gaddadfa was one of the weak tribes originating from the midlands, just between the West and the East" (Hanafi, 2014, p. 44), while the influence of dominating Barca tribes declined. As Colonel Gaddafi came to power on September 1, 1969 after leading a group of young Libyan military officers against King Idris I in a bloodless coup d'etat, he was careful to avoid conflicts with the tribes and with the monarchical ruling elites.

Gaddafi made three important moves. First, in September 1969, he began to build an alliance between four tribes: the Gaddadfa (Central Libya), Warfalla (in Tripolitania), Magarha (in Northern Fezzan) and al-Awaqir (Cyrenaica, between Derna and al-Bayda). Thanks to the central position, the watan of the Gaddadfa tribe became an essential junction for inter-tribe relations, including where economic resources were in question.

Second, in December 1969 he married the daughter of a Senussi high officer from the Magarha tribe (Report Libya, 2014), which could not only be considered an act of reconciliation with former elites, but also indicated that Gaddafi was their successor. 
Third, in July 1970 he married Safia Farkash of the Barasa tribe from Cyrenaica, and this was taken as a personal alliance between the leader and the people of Barca.

As was mentioned above, Barca was subjected to certain discrimination as Gaddafi leaned on his own tribe. Yet the alliance of the four tribes continued to strengthen and so did the influence of Safia. Thus, even if it seemed that Cyrenaica turned into an economic base but lost other values, in fact Gaddafi managed to create a semblance of Barca's participation in all state affairs. His methods of integrating different parts of Libya and different tribes worked very effectively. The conflicts between Arabs and Berbers were partially managed, and the most socially dangerous group - the youth-was integrated and disciplined into military, social, sports and other kinds of organizations and movements, usually led by close relatives of Gaddafi himself.

But Gaddafi also had another goal-to prevent the strengthening of local authorities that were not connected to his personal network of alliances. In order to constrain the tribes that could form an opposition, he successfully provoked several conflicts. And while during his reign these conflicts were part of his mode of governance, after his death they turned into a major factor of instability, with each tribe and tribal faction vying for territorial and economic gains. As the old Libyan saying goes, the tribe is great if it controls the desert, the mountains and the sea (that is, water/oil, agricultural land and ports).

Thus, the success of Senussi reign derived from its Islamic origin (a counterpart to ethnic relations and 'asabiyya (Ladjal, 2016, p. 10)), while the success of Gaddafi's reign came as a result of his personal achievements, agreements and the principle of charismatic rule. Tailoring these principles to nowadays Libya apparently faces certain difficulties.

First, an emphasis on Islam as a unifying force is not only considered dangerous by foreign political actors but is also seen as unacceptable by the tribes themselves. The Kingdom of King Idris, despite its Senussi network as a unifying factor, was essentially secular, while today's Islamism is based on radical ideas that are negatively perceived not only by Western democratic societies, but also by a greater part of the Muslim population and, to a larger extent, by the tribes. 
The tribes in their lifestyle rely on the customary law ('adat or 'urf (Report Libya, 2014)) that in many cases counters the religious law (shari' ${ }^{\prime}$ ), and reject the implementation of the shari'a in its radical form, for this would mean an end to their liberty (Report Libya, 2014). In tribal mentality, the possibility to adhere to 'adat is equal to liberty, as it is considered one of the main dignities of every tribe. In addition, radical Islamists usually stand up against the 'asabiyya principles, identifying them as belonging to the pre-Islamic "Ignorance Era." However, the Islamic concept of heteronomy, as opposed to the principle of tribal watans, becomes more and more appealing to even the tribal elites. This is manifested, above all, in the so-called "migrant crisis" resulting from people's free crossing of sovereign borders in an attempt to claim a new territory of habitat.

Although the tribes are occasionally considered the key source of current instability and factionalism, many analysts acknowledge that "the tribal nature itself pushes the tribes to fight against the Islamist movements and should be considered as an exclusively positive factor" (Inan, 2017).

The second point concerns Gaddafi's charismatic rule. It might be reproduced in modern Libyan society, but the main difficulty here is to find a person able to fill the shoes of the deceased leader. We argue that in the case of Libya any new democratic procedure such as a referendum can be implemented only under the strong rule of a charismatic leader who would be able to explain the need for it and legitimize its implementation. We argue that the recurrent failure to hold a referendum and/or an election in Libya by the UN and other international actors is largely due to the lack of such a figure in the contemporary Libyan political milieu.

\section{TWO GOVERNMENTS, TWO AUTHORITIES, SANS SOVEREIGNTY}

There are three centers of power in Libya today, although none of them controls any important structure and all of them can sometimes be ignored.

The first one is the Government of National Accord (GNA) with its Presidential Council (PC) under the leadership of Fayez Mustafa al- 
Sarraj. Its base of support is the Misrata Brigades. As the GNA is also present in Sabha, it can keep under control the lands of Warfalla and Gaddadfa - the main former allies of the Gaddafi regime.

Fayez Mustafa al-Sarraj has experience of addressing social problems, he has fairly good managing skills and knowledge about the inner nature of the state's social policy. But he does not seem to be a strong leader able to rule the state with an iron hand in crisis situations. Two main arguments may support him in getting appointment as the head of state.

First, al-Sarraj is a sort of compromise between different political forces. He is expected to maintain a semblance of political equilibrium in Libya and to contribute to its peaceful integration.

Second, al-Sarraj has close relations with senior figures (his VicePremier Ahmad Maitig is his relative, as Abd al-Rahman al-Suwaihili, the leader of the Union for Homeland party and former head of the High Council of State, is Maitig's uncle and a member of one of the two leading clans of Misrata (Lacher, 2011)). He is also suspected of connections with radical groups and movements, such as the Muslim Brotherhood. This makes him serve as a bridge between secular and religious actors.

Ahmad Maitig was a Libyan premier in May-June 2014 in the GNC, but since his election was somewhat disputable, the High Court ordered his and his cabinet's resignation. Maitig is an economist, not a politician, and that is why he is not expected to assume the role of the head of state.

The vice-premier from Cyrenaica is Ali al-Gatrani, and he is one of the most active and effective figures in the HoR. Also, he is a confidential agent of Khalifa Haftar, and his election ambitions are aimed at creating a connection between Tripoli and Tobruk, and their military groups. But as the HoR refused to recognize the GNA and the PC, Ali al-Gatrani boycotted the PC's activity and has since scarcely taken part in attempts to unite the country (Fitzgerald and Toaldo, 2016). His political line is quite clear: Libya needs federalization and must be divided into three regional autonomies, where the main role must be played by military commanders alongside politicians. 
Although al-Sarraj himself is not a strong political leader and his competence lies in economics rather than politics, he has a powerful and capable cabinet (Fitzgerald and Toaldo, 2016). It represents not only different regions and parties, but different spheres of activity and networks of influence. However, al-Sarraj's cabinet must first execute effective policy in Tripolitania and Fezzan, as the tribal elders in Cyrenaica will not consider it a legitimate authority until the GNA achieves success. The cabinet's competence must be confirmed not only by the seizure of Sirte, but also by establishing an adequate social system and restoring the damaged economy and infrastructure, as well as guaranteeing revenues for tribal groups. In other words, the GNA was expected to reassert the state's sovereignty but has so far failed to do so.

The HoR, represented by its spokesman Aguila Saleh Issa, officially replaced the GNC in the summer of 2014, but after that a new GNC was formed by the Islamist parties, and the HoR had to move from Tripoli to Tobruk. According to the Skhirat agreement, the HoR had to act alongside the GNA and the PC, but the greater part of HoR members disagreed, and continue to position themselves as the only legal ruling body of the state, making the HoR a model victim of Krasner's statism.

The HoR still enjoys the support of some states, such as Egypt, UAE, and Russia (and, maybe, France (Bibbo, 2017)). Its main military body (though being a subject of controversy) is the LNA, which the HoR is relying upon in all security matters. Its role is actually reduced to the narrow sphere of arbitration between the tribes and implementation of minor economic reforms. At the same time, being "the only legal government and legislature," the HoR does not lose hope of spreading its authority over the whole of Libya, and this is where its ambitions run counter to the actual level of its activities and effective policymaking capabilities.

The HoR can totally rely on the LNA, yet skeptical opinions about Haftar and the HoR are not rare. Although external support for them remains significant, the scale of their successes is modest: the LNA has not achieved any victory worth mentioning (Sizer, 2016), and its efficiency can be attributed to well-made propaganda rather than real military power as is alleged. 
HoR Speaker Aguila Saleh studied and worked in judicial institutions. Like al-Sarraj, he is not a politician or an inborn leader. On the other hand, his knowledge of the judicial system may help him settle disputes with Barca tribes and find a balance between 'adat, sharia, and the state law, which would be recognized by all sides in the conflict.

\section{THE THIRD GOVERNMENT AND THE ISLAMIST QUESTION}

The third center of power is the New GNC with the Government of National Salvation (GNS) as its ruling body. When the GNC was dismissed in April 2016, its Islamist core, headed by Khalifa al-Ghweil, unsuccessfully tried to grab power and replace al-Sarraj and his cabinet (Fitzgerald and Toaldo, 2016). However, in March 2017, the GNC lost its last base in Tripoli, and in fact the third government ceased to exist. Al-Ghweil himself was wounded, and all the political activity stopped (Fragile Ceasefire..., 2017).

The future of Islamism in Libya looks bleak, it is highly doubtful that it has a chance to take strong positions in society. Currently, there are two main centers of Islamism in Libya: one is the cities of Barca, such as Derna, and the other is Tripoli. In Barca, Islamist networks existed throughout the Italian occupation and the monarchical rule, but they were never radical. The Senussis were Sufi by nature, and that meant that their doctrine allowed a combination of Islamic dogma and 'adat. This approach predetermined the success of Senussis within the country's tribal structure, as it did not contradict the tribal law.

In Tripolitania, there was no such network, and Islamist elements were limited to isolated brotherhoods and official structures founded under the suzerainty of the Ottoman Empire. However, in 2011, the Tripoli communities were the first to "enjoy great financial and supply support... and to take the radical forms of Islamist ideology" (Khalil, 2018). The lack of the traditional Islamist base created a void that was eagerly filled by the radicals from different affiliations.

In Fezzan, different ethnic groups had different versions of Islam, and the common law dominated over sharia. Idris I was a religious figure, but his reign did not turn Libya into a religious state (and 
indeed he had no such goal). Muammar al-Gaddafi encouraged Islam because he needed to present himself as a tribal, military and religious leader at the same time, but he did not develop a network of Islamic institutions such as universities or fiqh schools. Islamism on Libyan soil lacks sufficient roots that could help spread it among the population.

In order to explain the reasons for the Islamist parties still existing and playing an important role in the country's politics, we have to acknowledge several factors.

Firstly, some Libyans have left the state and taken part in military campaigns in other territories such as Afghanistan and Iraq (Smits, 2013, p. 14).

Secondly, the vacuum of power attracts Islamist movements in general, and we must acknowledge that the Tunisian and Egyptian experience made Islamists improve their methods of filling the void. The cross-border heteronomy concept of ummah, as promoted by Islamist ideologues, has undoubtedly attracted scores of active disenfranchised young people.

Although there exists a strong argument in support of Madkhali Salafis' attaining strong positions in the Libyan political landscape (Fitzgerald, 2018), we argue that the two main reasons for the Islamists' failure-the tribal-secular nature of Libyan society and the discord between different groups of the radicals themselves-prevent them from building a unified core, or base. From this point of view, there are no strong reasons for the Islamists' political consolidation in Libya. The latest failures of the GNC and GNS to find any powerful allies and to put under their control any important structures in Tripoli confirm this thesis. However, one should not discard the High Council of State's recent re-branding attempt and voiced distancing of its new head Khaled al-Mishri from the infamous Muslim Brotherhood. The GNC and GNS still wield significant power inside the country and in the international arena and play a serious role in shaping Libya's future.

\section{MILITARY FORMATIONS AND THE SECURITY DILEMMA}

Every political center of power in Libya is supported by a number of military formations, which simultaneously play the role of the army and 
the security force. Due to the presence of several governments, these military bodies multiply, too: the LNA in the East; the Misrata Brigades, coupled with most of Tripoli brigades, in the West; and the so-called Libyan Shield Force in different parts of the state (Guide, 2016).

In fact, the LNA is not a regular army, but rather an alliance of different militias and tribes (Fitzgerald and Toaldo, 2016). They neither have a unified program nor are recognized by military seniors in the region. However, as Operation Dignity started with multiple private contacts, the LNA currently controls, or claims to control, quite a big part of Libya.

Haftar had two major goals. One was Benghazi (despite complicated relations with the al-Awaqir tribe and Derna) and the second was Misrata and Tripoli (Sizer, 2016). However, the siege of Benghazi lasted for quite a long time, and after the liberation of the city, Haftar faced the necessity to share power and influence with local tribal leaders. His refusal to transfer control over Benghazi to the al-Awaqir sheikhs led to a split within the LNA, and if Haftar does not find solution to the problem with al-Awaqir, he may face similar problems in the relationship with other tribes and clans. In the Libyan hierarchy built upon private contacts, trust is still a major factor.

Although Haftar has an air force support from the UAE and Egypt, his further success or failure in operations depends not on these forces or on the tribal core of his militias, but on his ability to make deals with urban inhabitants. And here lies the problem, as Haftar is considered by a large part of the Cyrenaica population a second Gaddafi, and while the clans of Barca feel nostalgic for the monarchy, they do not have such a feeling for the Gaddafi era (Lacher, 2013, p. 20).

The Misrata Brigades and Tripoli brigades like Rada (a Special Deterrent Force) control the only operating airport in the capital (Fitzgerald and Toaldo, 2016)) but they are not totally unified, as they are multiple (about 200 brigades (Report Libya, 2014)) and some of the leaders do not support the GNA. But the majority of the most respected figures in both camps are rather loyal to the PC, as the three key political figures (al-Sarraj, Maitig, and Suwaihili) are connected with the powerful Misratan clan. 
The Tripoli brigades now carry out the functions of the security force in the capital, replacing the police and opposing the Islamists. Their head is Mahdi al-Harati, who is well known as the founder of Liwaa al-Umma battalion in Syria that is now associated with the Free Syrian Army, and then as a major actor in the Battle of Tripoli. Mahdi alHarati is a former mayor of the capital, and being rather young and efficient in security activities, he has become popular with ordinary people and may one day turn into a military leader able to unite the forces of Tripoli and Misrata.

Leadership has become an urgent problem, as in January 2017 the Misrata Brigades announced their merger with the LNA, although they still describe Haftar as a rogue and have just declared their loyalty to "God Almighty and the state." The commander of Misrata Military Council, Ibrahim Beitulmal, is now popular as the conqueror of Sirte, and if he unites the brigades under his own command and cooperates with Tripoli commanders, this will undermine all of Haftar's efforts to become the main leader of all military forces in Libya.

An attempt was made recently to unify the Misrata Brigades. A couple of years ago there appeared a new group known as United Libya headed by a popular figure, Abdel Hamid al-Dabiba, and supported by important economic and social agencies. Al-Dabiba is not only a businessman with connections, but a person with experience in politics, able to settle conflicts and tackle different problems (political and economic) within one process.

In April 2017, a conference held in Moscow (Torin, 2017) had among its participants al-Dabiba himself; Muhammad Eshtevi, President of the Libyan Academy of Higher Education; and Muhammad Khalil Issie, head of the "The Great Man-Made River" project. The latter is important as it aims to rebuild the irrigation system created by Gaddafi to supply the coast with drinking water from the desert, and damaged by NATO air strikes. Rebuilding the system is a most urgent task facing the Libyan government, whatever its name.

Among other military forces, the Libyan Shield Force (LSF) is a common name for three different military groups (in Benghazi, in the west of Tripoli, and in the east of Tripoli) formally serving the GNC 
(Report Libya, 2014). It is considered a terrorist movement by both the GNA and the HoR, and, being outnumbered and lacking significant resources, it has a small chance of success. According to some reports, the LSF has disbanded itself and no longer plays any role in Libyan politics.

The Zintan Brigades, previously the most loyal allies of Haftar, are famous for having held in custody Saif al-Islam Gaddafi, the son of the deceased leader (Guide, 2016). Today he is believed to stay in the city, rallying militias and tribes. If he joins his efforts with neighboring BaniWalid, loyal to his sister Ayesha, they may form a strong alliance of several tribes and militias and spread their influence farther on, especially as Warfalla tribal chiefs in Bani-Walid and Zintan have a common foeMisrata and any Islamist movements (Hanafi, 2014, pp. 46-47).

The Zintan Brigades are not as diversified and large as the Misrata militias, but they have a strict organization. The main body is the Zintan Revolutionaries' Military Council, and the main commander is Mukhtar Khalifa Shahub (Report Libya, 2014). Shahub was once a navy officer and has experience in military activities. The Zintan Brigades also have a media network and can communicate with people through TV channels and Internet.

The Petroleum Facilities Guard (PFG) now holds a base on the coast of Barca, around the Ras-Lanouf oil port. It tried to organize oil trade since 2013, but when Operation Dignity began, some difficulties arose and the trade stopped. The PFG's leader Ibrahim Jadhran, who also became a prominent figure in the Cyrenaica Protection Force and Political Bureau of Cyrenaica (Report Libya, 2014), rallied some 15,000-20,000 fighters and opposed Khalifa Haftar; he even said that Haftar and ISIS were "two sides of the same coin" (Guide, 2016). He also made contacts with some authorities in the GNA, such as al-Mahdi al-Barghati (former minister of defense) who was his close ally. After Jadhran's defeat and the liberation of some oil ports by the LNA, the PFG lost monopoly over oil infrastructure and, consequently, political importance.

During the Libyan monarchy the social fabric of the country was kept together by, among other factors, a network of Islamic institutions, while 
in Ghaddafi's Libya it was his personal charisma and the network of his connections with tribal elders and elites. Since late 2011 there has been no factor, on the state level, that could contribute to the reunification of Libyan society or, at least, serve as an impetus for the main actors to compromise. Instead, there are multiple tribes controlling territories and infrastructure, numerous militias controlling the cities, and three governments, each positioning itself as the sole legitimate one.

There are several major centers of power in Libya. Two of them are governments. The first one is represented by Fayez al-Sarraj, the GNA, and the Misrata Brigades; the second one, by Abdallah al-Thani in alBayda, the HoR, and the LNA.

The former's power rests on two principles: representing all regions and groups, including Islamists and Gaddafi-era officials; and supporting the relationship between two important cities, Tripoli and Misrata. Its military assets are diversified and, probably, the most effective. Provisionally, projects for combining military, economic, political, security, and social power centers may prove successful. However, this government lacks strong leadership. Al-Sarraj and his closest assistants are economists who are helping restore Libya after the war (like Rafiq Hariri did in Lebanon), but they are much less fit for policymaking at times of crisis. So, they are able to gain support only in urban centers, where they can be efficient in restoring local infrastructure facilities in a short time. In the tribal environs of the villages and the desert, however, they face a permanent challenge to their legitimacy. To ensure the welfare of the inhabitants of such regions, al-Sarraj has to restore major economic infrastructure (oil pipelines, the water supply system, etc.); these tasks will require a long time for implementation and secure borders because the southern borders are still the main gateway for terrorists (Sayigh, 2016, p. 17). So, what is urgently needed here is cooperation between al-Sarraj and his allies from Misrata, and a clear focus on tackling social and economic problems.

The main advantage of the second power center is Haftar's personality. His style of waging war, ability to negotiate, and political propaganda skills have proven quite successful. At the same time, his 
camp has no working government, as neither the HoR nor al-Thani and his ministers are competent and fit enough to solve the problems in Barca or in the whole of Libya. Moreover, they lack initiative needed to efficiently cope with all challenges in due time.

To be successful, any government of Libya should take into account the demands of the tribes and rely on the support of the Libyans rather than endless help from abroad. Currently, there is no leader in Libya capable of acting without foreign support: the GNA is backed by Western powers, the LNA gets support from the UAE and Egypt, and Misrata is assisted by Turkey and Qatar (Fitzgerald and Toaldo, 2016). Finally, the political culture of the tribes demands a strong, charismatic leader able to rally the country in difficult times. Unfortunately, there is no such figure in sight, which has been borne out by the results of the recent election.

The main question is whether there is a prospect of non-state exterritorial actors gaining the upper hand and guiding the country to a state-negating future or whether there is a possibility of restoring the sovereign nation-state in Libya in line with the state-centric concept.

There are other questions important for Libya's future as well.

Is there an Islamist plan ready to be implemented in the country, especially in view of the recent rebranding attempt with Khaled alMishri as the head of the High Council of State, or will Libya maintain its secular character?

Will Libya embody the beginning of a new post-Westphalian track in the international setup or will it return into the stables of traditional structure? We hereby argue that the former option is more feasible today.

\section{References}

Abdo, I. and El Kamouni-Janssen, F., 2015. Addressing Libya’s Multiple Crises: When Violent Politics, Extremism and Crime Meet. CRU Policy Brief. The Clingendael Institute.

Bibbo, B., 2017. Can Russia Resolve Conflict in Libya? Al Jazeera. [online]. Available at: <http://www.aljazeera.com/indepth/features/2017/03/russiaresolve-conflict-libya-170316094138550.html> [Accessed 10 June 2019]. 
Borisov A., 2007. Liviya: rol plemennogo faktora. [Libya: the Role of the Tribal Factor]. IIMES. [online]. Available at: $<$ http://www.iimes.ru/?p=6596> [Accessed 12 June 2019].

Chuprygin A. and Matrosov V., 2018. The Effect of Dernization: Political Stalemate in Libya. ISPI (Italian Institute for International Political Studies), pp. 1-6. Italy, Milano.

Collombier, V., 2016. The Power Struggle behind the New "Battle of Sirte". Arab Reform Initiative. Paris.

Cramer, M., 2014. The Amazigh Question in Post-Gadhafi Libya. Academia. [online]. Available at: <https://www.academia.edu/10806852/The_Amazigh_ Question_in_Post-Gadhafi_Libya_April_2014_> [Accessed 10 June 2019].

Dustur, 1949. Dustur imarat Barqa [Constitution of Barca Emirate].

Elhag, A., 2012. The Sudanese Role in Libya 2011. World Peace Foundation. [online]. Available at: <https://sites.tufts.edu/reinventingpeace/2012/12/17/ the-sudanese-role-in-libya-2011/> [Accessed 9 June 2017].

Fetouri, M., 2015. How a Small Libyan Town Insulated Itself from Surrounding Chaos. Al-Monitor. [online]. Available at: <http://www.al-monitor.com/pulse/ originals/2015/10/libya-bani-walid-town-security-safety-self-governancechaos.html> [Accessed 10 June 2017].

Fitzgerald, M., 2018. What Happened to Political Islam in Libya. ISPI. [online]. Available at: <https://www.ispionline.it/it/pubblicazione/arc-crisis-menaregion-21387> [Accessed 02 February 2019].

Fitzgerald, M. and Toaldo M., 2016. A Quick Guide to Libya’s Main Players. ECFR. [online]. Available at: <http://www.ecfr.eu/mena/mapping_libya_ conflict> [Accessed 09 June 2017].

Fragile Ceasefire..., 2017. Fragile Ceasefire in Tripoli as Ghwell Ousted from Rixos. Libya-Anaysis.com [online]. Available at: <http://www.libya-analysis. com/fragile-ceasefire-in-tripoli-as-ghwell-ousted-from-rixos/> [Accessed 16 September 2019].

Guide, 2016. Guide to Key Libyan Militias. BBC. [online] Available at: <http:// www.bbc.com/news/world-middle-east-19744533> [Accessed 10 June 2019].

Hanafi, Kh., 2014. Khara'it al-qiwwa-l-qabaliyya wa-s-siyasiyya wa-l-djihadiyya fi-l-Libia ba'da-th-thawra [Constellation of Tribal, Political and Jihadist Actors in Post-Revolutionary Libya]. Madjallat Awraq ash-Sharq al-Awsat, 64, pp. 43-55. 
Inan, I., 2017. Kharita al-qaba’il fi Libia wa dawruha-l-asasiy fi-s-sira' [Map of Libyan Tribes and Their Contribution to the Revolution]. Raseef22. [online]. Available at: <https://raseef22.com/article/94644> [Accessed 30 September 2019].

Khalil, S., 2018. Al-fawa'il fi-l-azma-l-libiyya wa djuhud at-taswiya-s-siyasiyya [Factors Affecting the Libyan Crisis and Efforts towards a Political Settlement]. Al-Markaz al-'arabiy li-l-buhuth wa-d-dirasat. [online] Available at: <http:// www.acrseg.org/40688> [Accessed 30 September 2019].

Krasner, S., 1984. Approaches to the State: Alternative Conceptions and Historical Dynamics. Comparative Politics, 16(2), pp. 223-246.

Lacher, W., 2011. Families, Tribes and Cities in the Libyan Revolution. Middle East Policy Council. [online]. Available at: http://www.mepc.org/familiestribes-and-cities-libyan-revolution> [Accessed 10 June 2019].

Lacher, W., 2013. Fault Lines of the Revolution. Political Actors, Camps and Conflicts in the New Libya. SWP Research Paper. Berlin.

Ladjal, T., 2016. Tribe and State in the History of Modern Libya: A Khaldunian Reading of the Development of Libya in the Modern Era, 1711-2011. Cogent Arts \& Humanities. [online]. Available at: <https://www.cogentoa.com/ article/10.1080/23311983.2016.1183278> [Accessed 9 June 2019].

Nye, J. and Keohane, R., 1971. Transnational Relations and World Politics: An Introduction. International Organization, 25(3), pp. 329-349. [online]. Available at: <http://www.jstor.org/stable/2706043> [Accessed 01 Feb. 2019].

Report Libya, 2014. Report Libya: Militias, Tribes, and Islamists. Ministry of Foreign Affairs (Netherlands).

Sayigh, Y., 2016. Dilemmas of Reform. Policing in Arab Transitions. Carnegie Middle East Center.

Sizer, L., 2016. Khalifa Haftar and the Future of Civil-Military Relations in Libya. War on the Rocks. [online]. Available at: <https://warontherocks.com/2016/05/ khalifa-haftar-and-the-future-of-civil-military-relations-in-libya/> [Accessed 11 June 2019].

Smits, R., Janssen, F., Briscoe, I. and Beswick, T., 2013. Revolution and Its Discontents: State, Factions and Violence in the New Libya. CRU Report. The Clingendael Institute.

Thomson, J., 1995. State Sovereignty in International Relations: Bridging the Gap between Theory and Empirical Research. International Studies Quarterly, 39(2), pp. 213-233. 
Andrei V. Chuprygin, Larisa A. Chuprygina, Valery A. Matrosov

Torin A., 2017. Liviya: kak vyìti iz politicheskogo tupika? [Libya: How to Break the Political Deadlock?]. Mezhdunarodnaia zhizn'. [online]. Available at: $<$ https://interaffairs.ru/news/show/17383> [Accessed 11 June 2017].

Shibh at-taqsim, 2016. Shibh at-taqsim yaud ila Libia bada talwih iqlim Barka bi-l-infisal [Specter of Cleavage Revisits Libya after Cyrenaica Announces Secession]. Aawsat. [online]. Available at: <https://aawsat.com/home/ article/607261> [Accessed 16 September 2017].

Za'rab, S., 2016. An-nahr as-sina'i al-adhim [Great Man-Made River] [online]. Available at: <http://fezzan24.blogspot.ru/2016/09/blog-post_68.html> [Accessed 11 June 2017]. 